recent attempts at legislation-our want of unity. I venture to propose a remedy to this state of things, by asking the profession to come forward and establish a club upon the same footing and amongst the West-end clubs in Pall Mall or its vicinity. The laws of the Army and Navy, the University, and the East India Clubs, can easily form a nuclens for our own. Members residing in London would pay a larger sum annually than the cxtra urbem, and so on. What we want is a bond which shall unite us one to another. We want a home to which the country practitioner, the army or navy surgeon, can resort; and where, if need be, medical politics can be discussed pleasantly and with effect.

To such an establishment we could invite members of parliament to hear our views or to explain our wants; they will not venture into the dog-kennels we have hitherto met in. Assuming a position amongst the clubs of other professions, we shall be recognised for our liberality and the elegance of our mansion. The absurdities which beset our present condition will cease to exist. English, Scotch, and Irish holders of diplomas will shake hands. Physician, surgeon, and apothecary will cease to be distinctive marks within the walls. Dishonest men may drop even their dishonourable practices when pointed at by a well-ordered and magnificent club, pretending not to gentility, but eminent and powerful in the good quality of its members.

April, 1854. Yours very respectfully,

A. E.

\section{THE MEDICAL REFORM BILL.}

CONFEREACE AT THE ROYAL COLLEGE OF PHYSICIANS, LONDON. To the Eator of THE LANCET.

STR,-Medical Reform is shelved; every one who attended the conference in Pall Mall East on Tuesday last must be convinced that there is no prospect of carrying any efficient measure of reform, in the present session at any rate, unless we can contrive to throw overboard the Scottish corporation. To attempt to conciliate pigheaded obstinacy, to endeavour to persuade such men as Mr. Syme and Dr. Anderson to adopt any measure of reform distinguished for its equity and reasonableness, and in which selfishness and monopoly do not enter, is utterly futile.

If the Funglish Medical Reformers mean to make any progress they must sever themselves from the wizards of the north, and I do not see why we should not have a Medical Reform Bill for England, Wales, and Ireland, and let the Scotchmen take care of themselves-which they are well calculated to do. We can do very well without them. Let us then combine and have a measure to regulate the education and practice of medical men in England, Wales, and Ireland, and prohibit Scotchmen, unless they have the English licence, practising in this part of the kingdom. This will soon bring the oracles of the north to their senses. Yesterday Professor Syme spoke at the conference no less than fourteen times, and each time his harangue contained its customary amount of egotism and dogmatism.

If the manner in which the business was conducted yesterday be a fair specimen of the way in which medical men manage reform matters, no wonder we are so long without reform. Every two were at issue as to the objects of the meeting, and proposed all kinds of illegal and informal resolutions; most of the speakers flatly contradicted themselves, and each other many spoke at least a dozen times, and often five or six were speaking at once. - Sir C. Hastings proposed that the conference should nominate a committee; the resolution was carried, bat no committee was nominated. The greatest incoherence and confusion prevailed, when Sir John Forbes, who might have known better, proposed that the meeting should adjourn till nine o'clock, in order that the gentlemen assembled might have their dinners. It struck me most forcibly that they had already dined.

Dr. Paris attempted to read letters he had received; he could not make out the writing, and no one could understand his interpretation of them. Would it not be as well, in order to avoid the waste of valuable time, to have " a reader" possessed of a clear vision, and with an articulate tongue, on the next occasion of a conference ? and ought not the members of it to be admonished not to intrust the papers, on which the discussion is to take place, to the care of a clerk who is not to be found when the papers are wanted and the gentlemen are assembled ? Half an hour was lost in this manner yesterday.

After three hours' sitting, and a great deal of talking and wrangling - when it seemed utterly impossible that any definite understanding conld be come to, and when the speakers did not seem very well to know what they were talking about, or for what purpose they were assembled, Dr. Paris abruptly adjourned the meeting sine die, and in this manner ended the reat " conference" of 1854, and with it, I fear, all prospects of Medical Reform.

I am, Sir, your most obedient servant, Half Moon-street, Piceadilly, April, 185t. BUlBous RooTz, M.D.

\section{THE VACCINATION EXTENSION ACT.}

To the Editor of THE LANCET.

SIR,-I agree with your correspondent in thinking that every duly-qualified practitioner should be a public vaccinator. One fee of $2 s$. or $2 s .6 d$. ought to be charged instead of a fee according to distances. The registrars would pay the account quarterly, and the work would be done better by several competitors, and more to the satisfaction of the patients, who generally prefer their own medical men. Until a more liberal measure is devised, am I at liberty to send a duly-qualified assistant to vaccinate for me, and can I authorize him to do so in case I am absent from home or otherwise engaged? Would the guardians be bound to pay me in such a case? I am not always able to attend at the time prescribed, and should be glad of your opinion as to the proper course to adopt under such circumstances.

Northwich, Cheshire, April, 1854 I am, Sir, yours faithfully

* A duly qualified assistant could legally attend; payment would be awarded to his principal.

THE LATE CASE OF FENNELL $v$. ADAMS.

[METTER FROM MR. FENNELL.]

To the Editoi of 'THE Laxcet.

SIR, - Will you permit me this opportunity of expressing my acknowledgment to you for your approval of my conduct, so strongly urged in your excellent journal in. July last; and at the same time to say a few words expressive of my gratitude to those gentlemen who kindiy formed themselves into a com. mittee with the object of defraying my expenses in the action which I brought against the Rev. Richard L. Adams for slander. My thanks are also sincerely offered to those of my professional bretbren and others, (amongst the latter of whom are many clergymen) for the liberal pecuniary aid they have given me; and, although a considerable balance is left against me, I should desire members of the profession similarly situated with myself to know that I have had no reason to regret the course I adopted.

Certainly, in very simplicity, I did not for a moment suppose that the defendant would have availed himself of the ignominious plea upon which he escaped.

Wimbledon, Aprit, 185 s,

$$
\text { I am, Sir, your obedient servant, }
$$
EDwin Fennel.

\section{THE ROYAL FREE HOSPITAL. To the Editor of THE LANCET.}

SIR,-I am quietly practising my profession in the country, remote from the scene of the late controversy between $\mathrm{Mr}$. Gay and the Royal Free Hospital, and know nothing of either party beyond what the medical journals communicate. I have read and examined both sides of the question; I have also noticed with some degree of pain Mr. de Morgan's proceeding with respect to THE LAYCET; and in consequence of seeing the very sensible letter in your number of April 8th, signed "A Hospital Surgeon," I cannot resist intruding this note on you, to say how truly and clearly it expresses the conclusion to which I and all my brother country practitioners with whom I have conversed have arrived. The last paragraph of the admirable letter referred to, and which I would here quote, is the summing up of an impartial judge. I would especially call the attention of your readers to it. With respect to the allusions of the writer to your journal, I, after subscribing to it for twenty-five years, say "Amen" to them :-

"It is impossible not to admire the manner in which a large number of our profession came forward to defend one whom they believed to be an injured brother; but the same high tone of honour, keen sensibility, and chivalrous feeling that prompted this ready response to a call from one who assumed the garb of martyrdom, must, by degrees, bring about a reaction. Many will see how difficult it is to disconnect Mr. Gay from that sad piece of fulscme adulation, ranity, and spleen, that was published as his biography, since he had the proof-sheets in hs possession, circulated the pamphlet amongst his friends, and refused to discountenance its contents, or publicly to disavow 